\title{
THERAPEUTIC MUD OCCURRENCES IN GREECE: MINERALOGICAL AND GEOCHEMICAL COMPOSITION OF THE SAGIADA MUD (THESPROTIA PREFECTURE)
}

\author{
Athanassoulis C. ${ }^{1}$, Zaimis S. ${ }^{1}$, Chatziapostolou A. ${ }^{1}$ and Agalaniotou S. ${ }^{1}$ \\ ${ }^{1}$ Institute of Geology and Mineral Exploration, Spiros Louis St. 1, Olympic Village, 13677, \\ Acharnes,Greece,athanc@igme.gr,szaimis@gmail.com,achatzia@gmail.com, \\ sagalani@hotmail.com
}

\begin{abstract}
The current study presents the preliminary results of the mineralogical and geochemical characterization of the Sagiada mud (Prefecture of Thesprotia), which is considered as one of the most representative therapeutic mud occurrences in Greece. This work is part of a bigger project, conducted by IGME (Athens, Greece), for the characterization of the Greek therapeutic mud deposits. The mineralogical composition was determined using X-Ray Diffraction (XRD), Differential Thermal Analysis (DTA), optical microscopy and Scanning Electron Microscopy (SEM). The main mineral phases of the Sagiada mud are quartz, feldspars, clay minerals such as illite, kaolinite, chlorite and vermiculite, and calcite accompanied by minor phases such as halite and pyrite. Traces of muscovite and gypsum were also identified. Geochemical analyses were performed using X-Ray Fluorescence (XRF) and Inductively Coupled Plasma-Mass Spectrometry (ICP-MS) for the determination of major and trace element content, respectively. Compared to Spanish peloids and European floodplain sediments, the Sagiada mud reveals an analogue chemical composition.
\end{abstract}

Keywords: mud-therapy, clay minerals, mineralogy, geochemistry.

\section{Пері́ $\eta \psi \eta$}

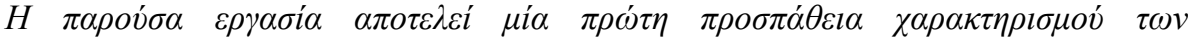

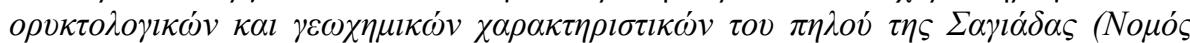

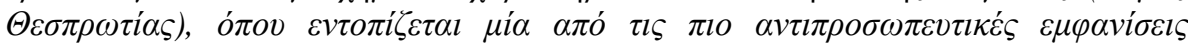

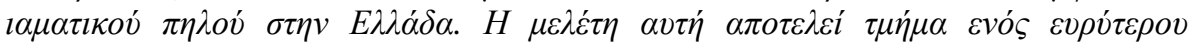

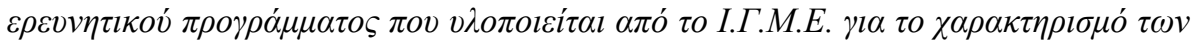

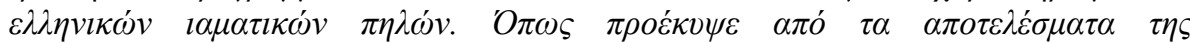

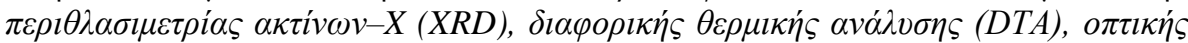

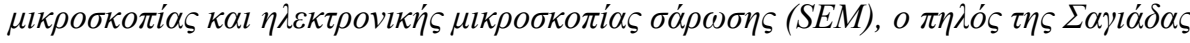

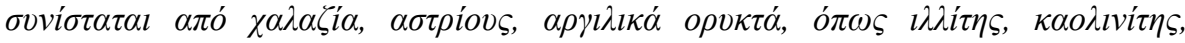

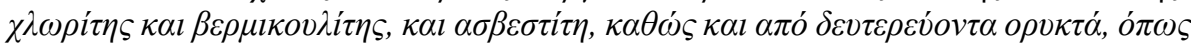

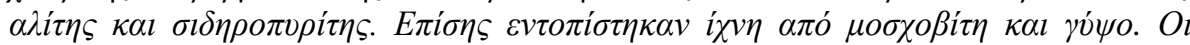

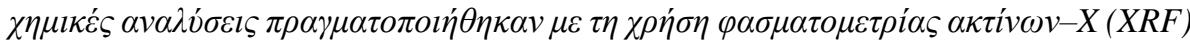

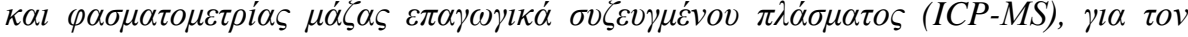
$\pi \rho о \sigma \delta$ lo

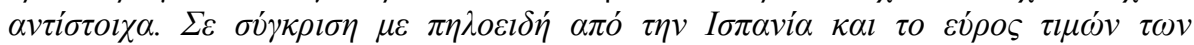




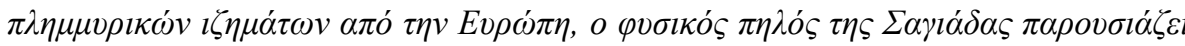

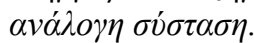

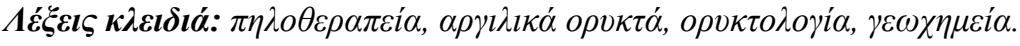

\title{
1. Introduction
}

The empirical use of clays and muds for therapeutic purposes is known since antiquity, with the most common uses to be the ingestion and skin application in the form of patches, cataplasms or mud-baths (Gomes and Silva, 2007). In ancient Greece, mud materials, known as medical earths (Terrae), were often named after their origins. They were used as antiseptic cataplasms to cure skin afflictions or as a cure for snake-bites (Carretero, 2002). Example of medical earths is the Terra Lemnia, from Lemnos Island in North Aegean Sea, which was known as a pharmaceutical product from antiquity until the $19^{\text {th }}$ century.

Nowadays, clay minerals, such as smectites, palygorskite, kaolinite and talc, are used in pharmaceutical formulations as well as in spa-centers and aesthetic medicine for therapeutic purposes (Carretero, 2002). According to Veniale et al. (2007), pelotherapy, which is the use of thermal muds for muscle-bone-skin pathologies treatment, is also applied for wellness and relaxation. Though, since the natural reserves of thermal muds are limited, many spa-centers produce the thermal mud by "maturation" (Veniale et al., 2007). Maturation is a process of mixing natural sediments potentially interesting for therapeutic or cosmetic purposes, with mineral water or seawater, or particularly with medicinal mineral water (Gomes et al., 2013). According to Gomes et al. (2013), mud is also applied in the natural environment, where it occurs, in the form of mud-packs, mud-baths or facial masks, sometimes in an empirical way, for healing or cosmetic purposes, in a practice so-called "mud-therapy". In Greece, mud-therapy is widely known and applied, especially during the summer period.

The current study is part of a project for the characterization of Greek mud deposits, used for therapeutic purposes. The project is funded by the European Union (NSRF 2007-2013, code 350913). In the framework of this project, mineralogical, geochemical and physicochemical analyses were carried out at the Institute of Geology and Mineral Exploration (IGME), Athens, Greece, in order to assess the suitability of Greek muds for therapeutic use. The studied areas include the Sagiada mud occurrences (Thesprotia, Epirus), the mud sediments of the Aetolikon - Messolonghi lagoon, local occurrences at Western Greece (such as Kyllini, Kaiafas Lake, Mytikas Xiromero and places of interest in Ambracian Gulf), as well as Argos (Eastern Peloponnese), Aedipsos (Evia Island) and the Aegean Islands Milos, Kos and Lemnos. An integrated database was designed and developed, in order to present general information, as well as the physicochemical, mineralogical and chemical properties of the studied mud occurrences. This study enhances the importance of these natural resources for local communities, on the base of potential exploitation through the development of medical tourism, entrepreneurship, and the use of natural reserves as raw material for spa-centers. In addition to the above, some other locations for mud-therapy in Greece are Krinides (Kavala Prefecture), Pikrolimni Lake (Kilkis Prefecture), Kavasila (Ioannina Prefecture), Vromolimni Lake of Methana (Attica Prefecture), Santorini Island, Amynteo (Florina Prefecture), Samos Island, Astros (Arkadia Prefecture) and the Anargiroi basin (Florina Prefecture) (Aggelidis, 1990).

Herein the case study of the Sagiada mud is presented, as it is considered one of the most representative natural therapeutic muds in Greece and is traditionally used for mud-therapy, both insitu and in a local Mud-Therapy Center, after a beneficiation process. According to a previous study of the Sagiada mud, it is designated safe for use due to the restricted mobility of trace elements in water solution (Mitrakas, 2009). The present work examines in detail the mineralogical composition of the natural mud, the clay mineral content and the chemical composition. 


\section{Geological Setting}

The study area is located in the Sagiada Bay of Thesprotia, NW Greece (Figure 1), a region that geotectonically belongs to the Ionian Zone.

Specifically, the area consists of sediments of Neogene to Quaternary age, including marls and recent alluvial deposits, mainly originate from the Thyamis (Kalamas) River. The lagoon environment that is formed extends in a SSW direction from the Sagiada settlement to the most recent deltaic deposits of Thyamis River, which is approximately $5 \mathrm{~km}$ far.

The Alpine basement outcropping in the area consists of a sedimentary sequence, which overlies the formation of Permo-Triassic evaporites. The base of this sequence consists of neritic limestones and dolomites, while the upper parts of Jurassic to Eocene age, consist of semi-pelagic to pelagic formations such as limestones, schists with Posidonia and cherts. Flysch sediments were deposited from Late Eocene to Early Miocene (Aquitanian); consist of sandstones, siltstones and marls (Perrier and Koukouzas, 1969; Mountrakis, 2010).

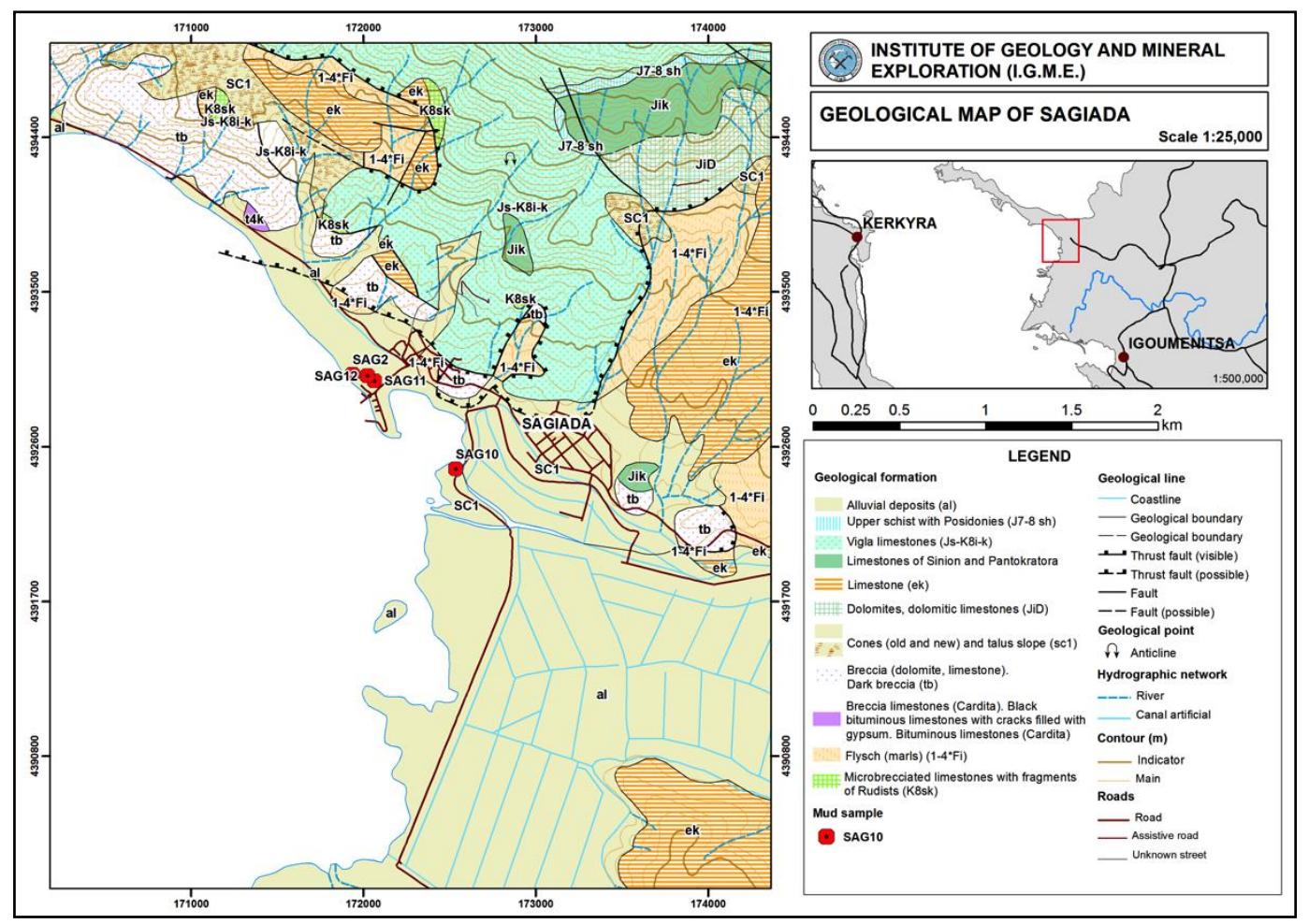

Figure 1 - Geological map of Sagiada (modified after Perrier and Koukouzas, 1969).

\section{Materials and Methods}

Six core sediment samples, approximately $2 \mathrm{~kg}$ each and up to $70 \mathrm{~cm}$ depth, were collected for mineralogical and geochemical analysis. The sampling locations are presented in Figure 1. The samples were dried, homogenized and pulverized using an agate mill at -200 mesh. The mineralogical composition was determined by four analytical techniques, such as X-Ray Diffraction (XRD), Differential Thermal Analysis (DTA), transmitted-light optical microscopy and Scanning Electron Microscopy (SEM), carried out at the Laboratories of Mineralogy and Petrology of the Institute of Geology and Mineral Exploration (IGME). X-Ray Diffraction analyses were performed using a Panalytical X' Pert PRO diffractometer with $\mathrm{CuK} \alpha$ radiation and the scanning area covered 
the interval $2 \theta 3-70^{\circ}$, with a scanning step of $0.03^{\circ}$ and a step time of $3 \mathrm{~s}$. Clay minerals were identified on the bulk samples $\left(2 \theta=3-60^{\circ}\right)$, as well as on the samples after treatment with ethylenoglycole $\left(2 \theta=3-30^{\circ}\right)$ and after heating at $490^{\circ} \mathrm{C}$ for $2 \mathrm{~h}\left(2 \theta=3-30^{\circ}\right)$, with a scanning step of $0.03^{\circ}$ and a time step of $3 \mathrm{~s}$ (Gee and Bauder, 1986; Moore and Reynolds, 1997). The mineral phases were identified with the use of EVA ${ }^{\circledR}$ software and semi-quantitative determination was performed using the X-Pert High Score software provided by Bruker. The DTA analyses were carried out with a DTG-60AH, in temperature range $30-1100{ }^{\circ} \mathrm{C}$ and step time $10{ }^{\circ} \mathrm{C} / \mathrm{min}$, using $\mathrm{N}$ gas with 50 $\mathrm{ml} / \mathrm{min}$ flow. The optical microscopy was performed using a Zeiss AXIOSKOP 40 polarized-light microscope and the Scanning Electron Microscopy using a JEOL-JSM 5600, with associated Energy Dispersive Spectroscopy analyzer (EDS). Major element composition was determined by X-Ray Fluorescence (XRF) at the Laboratories of Mineralogy and Petrology of IGME, using a S4 Pioneer Bruker AXS (for $\mathrm{SiO}_{2}, \mathrm{TiO}_{2}, \mathrm{Al}_{2} \mathrm{O}_{3}, \mathrm{MnO}, \mathrm{MgO}, \mathrm{CaO}, \mathrm{Na}_{2} \mathrm{O}, \mathrm{K}_{2} \mathrm{O}, \mathrm{P}_{2} \mathrm{O}_{5}, \mathrm{Fe}_{2} \mathrm{O}_{3}$ and $\mathrm{SO}_{3}$ ). Trace element concentrations were determined in solutions, which were prepared after open vessel digestion with Aqua Regia, applying Inductively Coupled Plasma - Mass Spectrometry (ICP-MS) at the Analytical Laboratories of IGME (for As, $\mathrm{Ba}, \mathrm{Be}, \mathrm{Cd}, \mathrm{Co}, \mathrm{Cr}, \mathrm{Cs}, \mathrm{Cu}, \mathrm{Mo}, \mathrm{Ni}, \mathrm{Pb}, \mathrm{Sb}, \mathrm{Se}, \mathrm{U}$, $\mathrm{V}$ and $\mathrm{Zn}$ ). The Loss on Ignition was measured after heating the samples at $1000{ }^{\circ} \mathrm{C}$ for $3 \mathrm{~h}$, at the Analytical Laboratories of IGME.

\section{Discussion and Results}

The studied material, a natural mud from the Sagiada lagoon, represents sediments used for therapeutic purposes both in the natural environment and in a local Mud-Therapy Centre, close to the Sagiada settlement. The studied samples originate mainly from the local Mud-Therapy Centre, as well as from distal places to the SSW (Figure 1).

\subsection{Mineralogical Composition}

The semi-quantitative determination of the mineral matter of the Sagiada natural mud reveals that quartz (28-33 wt.\%), feldspars (6-14 wt.\%), clay minerals such as illite (10-17 wt.\%), kaolinite, (37 wt.\%), chlorite (4-6 wt.\%) and vermiculite (4-11 wt.\%), and calcite (17-26 wt.\%) are the main mineral phases (Table 1). Halite (2-3 wt.\%) and pyrite (1-3 wt.\%) constitute minor phases (Table 1). Clay mineral identification was carried out especially using X-Ray Diffraction (XRD) in the clay fraction of the samples (Figure 2), as well as using Differential Thermal Analysis in the bulk samples (DTA) (Figure 3). Carbonate components occur in the form of cryptocrystalline aggregates (Figure 4a); whereas pyrite is often found in the form of framboids (Figure 4b). Traces of muscovite and gypsum were observed by transmitted-light microscopy.

In the study area, quartz, clay minerals (illite, chlorite) and feldspars have a clastic origin (Drees et al., 1989; Huang, 1989), deriving from the weathering and erosion of the surrounding Neogene and Quaternary rocks. Vermiculite and kaolinite are formed from the weathering of mica and chlorite and rarely by feldspars alteration (Paquet and Clauer, 1997). Calcite has clastic or authigenic origin (Doner and Lynn, 1989; Paquet and Clauer, 1997) from Ca-rich waters originated from limestone and evaporite dissolution. Halite may have clastic and/or authigenic origin or derive from the sea spray (Doner and Lynn, 1989; Paquet and Clauer, 1997). Pyrite in coastal mires is usually found in the form of framboids. Their formation is due to the reduction of the seawater sulphates and the reaction of the $\mathrm{H}_{2} \mathrm{~S}$ with $\mathrm{Fe}$-ions, which derive from detrital material entering the mire during flood episodes (Dellwig et al., 2001).

\subsection{Chemical Composition}

The major and trace element composition is presented in Table 2 along with the compositional range of Spanish peloids (Carretero et al., 2010; Carretero et al., 2014), and floodplain sediments according to the Geochemical Atlas of Europe (FOREGS, 2005). The major element concentrations display a significant resemblance, as shown in Figure 5, except from $\mathrm{CaO}$, which ranges between 10.46 and $17.39 \mathrm{wt} . \%$ and $\mathrm{SO}_{3}$, which ranges between 0.93 and $2.16 \mathrm{wt} . \%$. Compared to the 
Spanish peloids, the Sagiada mud has a typical composition. Regarding trace element content, Ba, $\mathrm{Ni}, \mathrm{Cr}, \mathrm{Zn}$ and $\mathrm{V}$ were the most abundant elements (above $100 \mathrm{mg} / \mathrm{kg}$ ), whereas $\mathrm{Cu}, \mathrm{Co}, \mathrm{Pb}, \mathrm{As}, \mathrm{Mo}$, $\mathrm{U}, \mathrm{Be}, \mathrm{Cd}$ and $\mathrm{Sb}$ occur in lesser amounts. Compared to the Spanish peloids, the Sagiada mud is enriched in $\mathrm{Ni}$ and $\mathrm{Cr}$ and slightly in $\mathrm{V}$ and $\mathrm{Co}$, but their concentrations seem reasonable compared to the compositional range of the floodplain sediments from Europe (FOREGS, 2005). Compared to floodplain sediments from Europe (FOREGS, 2005), the Sagiada mud occurs slightly enriched in $\mathrm{SO}_{3}$. Although, background element concentration is essential in order to assess their origin.

Table 1 - Mineralogical composition of the Sagiada natural mud, as identified using X-Ray Diffraction analysis (in wt.\%) (tr: traces, below 3 wt.\%).

\begin{tabular}{|l|c|c|c|c|c|c|}
\hline & SAG2 & SAG10a & SAG10b & SAG11a & SAG12a & SAG12b \\
\hline Quartz & 28 & 30 & 33 & 33 & 31 & 32 \\
\hline Feldspars & 10 & 11 & 12 & 6 & 14 & 13 \\
\hline Illite & 11 & 15 & 17 & 13 & 10 & 16 \\
\hline Kaolinite & 6 & 6 & 7 & 7 & 5 & 3 \\
\hline Chlorite & 4 & 6 & 6 & 4 & 4 & 4 \\
\hline Vermiculite & 11 & 9 & 4 & 7 & 11 & 9 \\
\hline Calcite & 25 & 18 & 18 & 26 & 22 & 17 \\
\hline Halite & 3 & $t r$ & $t r$ & 3 & $t r$ & 3 \\
\hline Pyrite & $t r$ & 3 & $t r$ & $t r$ & $t r$ & 3 \\
\hline
\end{tabular}

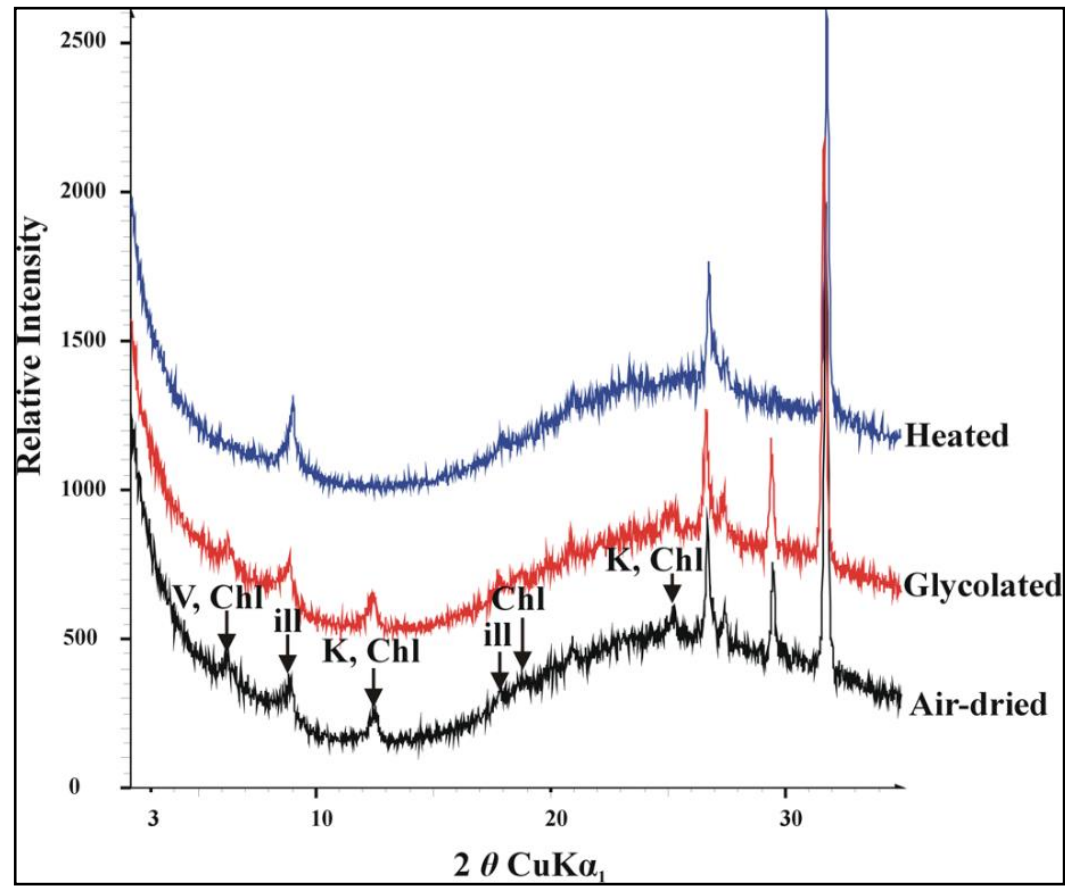

Figure 2 - Clay mineral identification using X-Ray Diffraction (XRD) in the clay fraction of the sample SAG2 (V: Vermiculite, Chl: Chlorite, ill: illite, K: Kaolinite). 


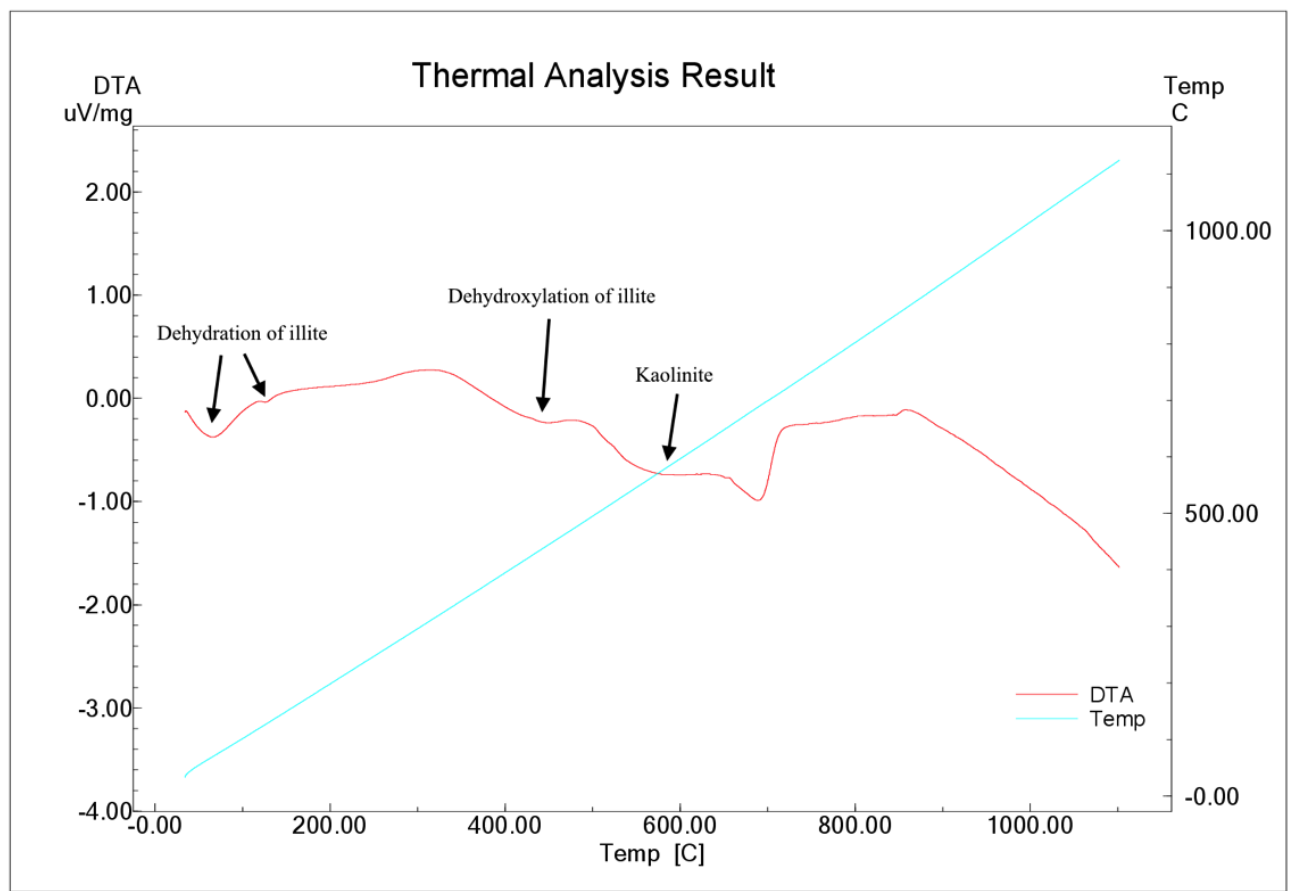

Figure 3 - Differential Thermal Analysis (DTA) of a sample from the Sagiada mud (SAG11).
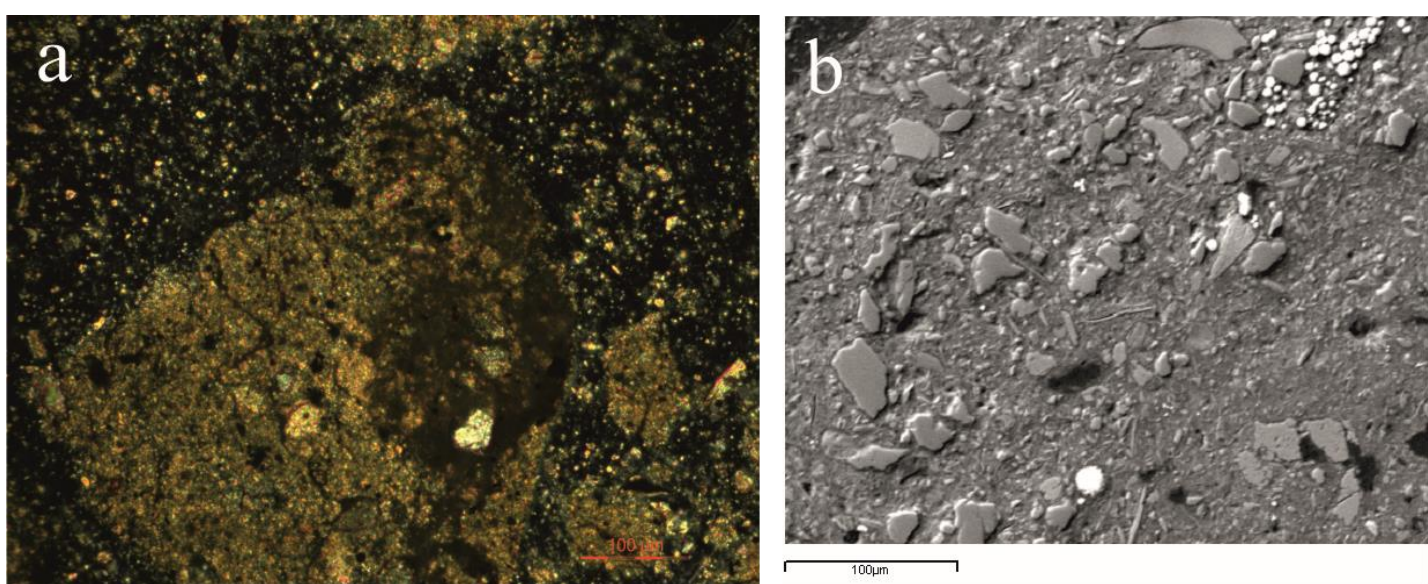

Figure 4 - a) Aggregates of carbonate components and clay minerals from the Sagiada mud, transmitted-light microscopy image, $+N$, b) SEM image of framboidal pyrite found in the

Sagiada mud. 
Table 2 - Chemical composition of the Sagiada mud.

\begin{tabular}{|c|c|c|c|c|c|c|c|c|c|}
\hline & SAG2 & SAG10A & SAG10B & SAG11 & SAG12A & SAG12B & Mean & $\begin{array}{l}\text { Spanish } \\
\text { peloids }\end{array}$ & $\begin{array}{c}\text { Floodplain } \\
\text { sediments }\end{array}$ \\
\hline $\mathrm{SiO}_{2}$ & 35.18 & 43.77 & 44.61 & 41.59 & 40.33 & 39.67 & 40.86 & $18.41-51.12$ & $7.90-100$ \\
\hline $\mathrm{TiO}_{2}$ & 0.41 & 0.55 & 0.53 & 0.46 & 0.47 & 0.47 & 0.48 & $0.22-0.55$ & $0.05-2.15$ \\
\hline $\mathrm{Al}_{2} \mathrm{O}_{3}$ & 8.56 & 10.87 & 10.64 & 9.79 & 9.99 & 9.73 & 9.93 & $3.58-12.24$ & $0.10-32.6$ \\
\hline $\mathrm{MnO}$ & 0.10 & 0.13 & 0.11 & 0.09 & 0.10 & 0.12 & 0.11 & $0.02-0.61$ & $<0.01-6.61$ \\
\hline $\mathrm{MgO}$ & 3.89 & 5.01 & 4.64 & 3.85 & 3.96 & 4.20 & 4.26 & $0.98-22.35$ & $<0.1-17.2$ \\
\hline $\mathrm{CaO}$ & 17.39 & 10.51 & 10.46 & 13.42 & 13.44 & 14.03 & 13.21 & $2.27-26.48$ & $<0.05-54.4$ \\
\hline $\mathrm{Na}_{2} \mathrm{O}$ & 1.80 & 1.75 & 1.78 & 1.53 & 1.55 & 1.59 & 1.67 & $0.3-4.34$ & $<0.2-3.70$ \\
\hline $\mathrm{K}_{2} \mathrm{O}$ & 1.77 & 2.30 & 2.21 & 2.01 & 2.06 & 2.02 & 2.06 & $0.57-2.57$ & $0.11-5.10$ \\
\hline $\mathrm{P}_{2} \mathrm{O}_{5}$ & 0.11 & 0.12 & 0.11 & 0.12 & 0.11 & 0.10 & 0.11 & $n r$ & $<0.01-2.61$ \\
\hline$\underset{\mathrm{T}}{\mathrm{Fe}_{2} \mathrm{O}_{3}}$ & 4.43 & 6.12 & 5.65 & 4.85 & 4.98 & 5.06 & 5.18 & $1.7-5.24$ & $0.25-35.8$ \\
\hline $\mathrm{SO}_{3}{ }^{\mathrm{T}}$ & 1.83 & 0.93 & 2.16 & 1.57 & 1.81 & 2.16 & 1.74 & $0.06-2.37$ & $<0.01-1.36$ \\
\hline LOI & 24.52 & 17.94 & 17.1 & 20.71 & 21.19 & 20.86 & 20.39 & $13.95-53.84$ & $n r$ \\
\hline As & 10 & 11 & 11 & 11 & 11 & 19 & 12 & $4.4-29.6$ & $<5.0-410$ \\
\hline $\mathrm{Ba}$ & 160 & 239 & 212 & 182 & 184 & 237 & 202 & $147.7-799$ & $7.00-2210$ \\
\hline $\mathrm{Be}$ & 1 & 2 & 2 & 2 & 3 & 2 & 2 & $n r$ & $<0.02-47.5$ \\
\hline $\mathrm{Cd}$ & $<1$ & 1 & 1 & 1 & 1 & 1 & 1 & $<10$ & $<0.02-23.6$ \\
\hline Co & 21 & 26 & 27 & 22 & 24 & 24 & 24 & $4-16.8$ & $<1.0-55.0$ \\
\hline $\mathrm{Cr}$ & 125 & 184 & 195 & 146 & 148 & 163 & 160 & $14.6-68.2$ & $3.00-1600$ \\
\hline Cs & $<10$ & $<10$ & $<10$ & $<10$ & $<10$ & $<10$ & $<10$ & $<6-28.5$ & $<4-40.0$ \\
\hline $\mathrm{Cu}$ & 53 & 50 & 47 & 58 & 54 & 46 & 51 & $11.5-52.3$ & $1.00-421$ \\
\hline Mo & 5 & 2 & 3 & 3 & 3 & 5 & 4 & $<1-4.4$ & $<0.05-191$ \\
\hline $\mathrm{Ni}$ & 164 & 194 & 202 & 154 & 157 & 166 & 173 & $3.4-50.8$ & $2.00-942$ \\
\hline $\mathrm{Pb}$ & 21 & 22 & 18 & 22 & 21 & 19 & 21 & $10.9-37.5$ & $<3.0-5200$ \\
\hline $\mathrm{Sb}$ & 0.9 & 0.9 & 0.8 & 1.15 & 0.9 & 1.3 & 1 & $<2.37-4.3$ & $<0.02-99.4$ \\
\hline $\mathrm{Se}$ & $<1$ & $<1$ & $<1$ & $<1$ & $<1$ & $<1$ & $<1$ & $<1-1.6$ & $n r$ \\
\hline $\mathrm{U}$ & 3 & 2 & 3 & 3 & 3 & 3 & 3 & $<1.20-18.4$ & $<1.0-89.0$ \\
\hline $\mathrm{V}$ & 93 & 117 & 115 & 118 & 118 & 109 & 112 & $31.6-90.9$ & $3.00-140$ \\
\hline $\mathrm{Zn}$ & 207 & 124 & 105 & 122 & 116 & 129 & 134 & $\begin{array}{l}33.1- \\
160.4\end{array}$ & $\begin{array}{l}7.00- \\
2830\end{array}$ \\
\hline
\end{tabular}

Major elements in wt.\% and trace elements in $\mathrm{mg} / \mathrm{kg}$. $\mathrm{Fe}_{2} \mathrm{O}_{3}$ and $\mathrm{SO}_{3}$ refer to total iron and sulphur, respectively. The major element composition is normalized so that the addition of LOI results 100. The compositional range of Spanish peloids is after Carretero et al. (2010) and Carretero et al. (2014), and the compositional range of European floodplain sediments is after FOREGS (2005). nr: not referred. 


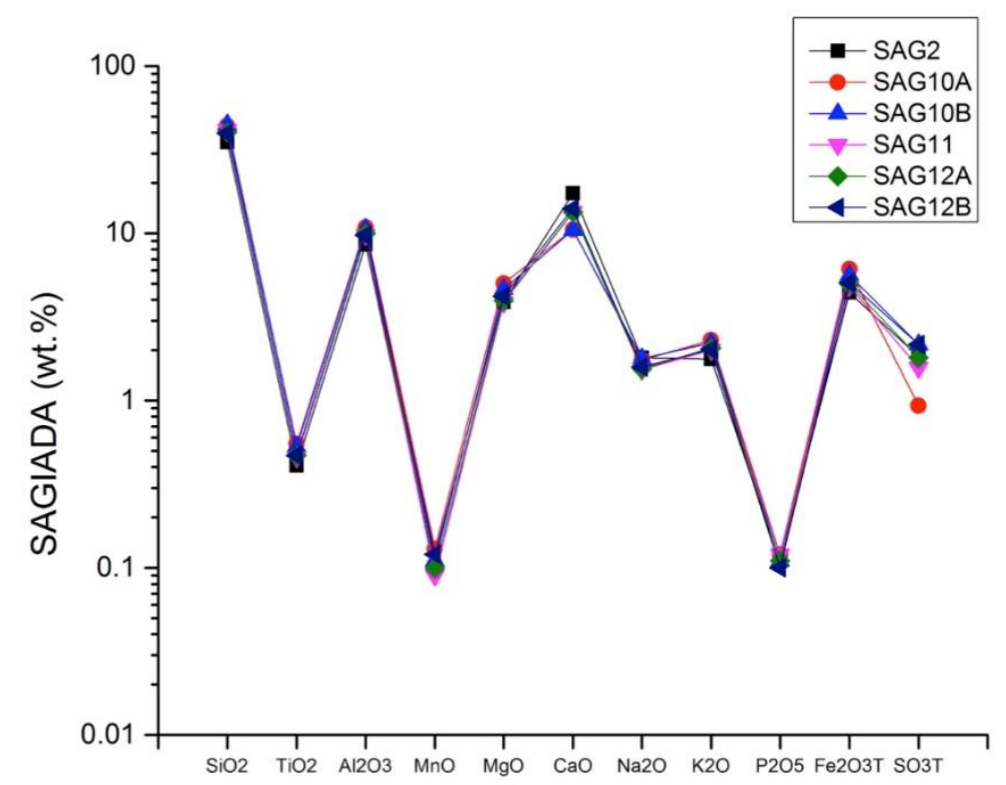

Figure 5 - Major element composition of the Sagiada mud.

\section{Concluding Remarks}

The Sagiada natural mud occurrences display a significant resemblance in terms of mineralogical and chemical composition. The main mineral phases are quartz, feldspars, illite, kaolinite, chlorite, vermiculite and calcite and minor phases are halite and pyrite. Traces of muscovite and gypsum were also identified. Compared to peloids used in Spanish spas, the Sagiada mud is enriched in Ni, $\mathrm{Cr}$ and slightly $\mathrm{V}$ and $\mathrm{Co}$, but those concentrations are within the compositional range of floodplain sediments from Europe. The Sagiada mud, compared to the floodplain sediments from Europe has slightly elevated $\mathrm{SO}_{3}$ concentrations, which are reasonable for therapeutic muds, as indicated by the comparison with Spanish peloids.

\section{Acknowledgements}

The project is funded by the European Union (National Strategic Reference Framework 2007-2013, code 350913). We would like to thank Dr. G. Vougioukalakis, M. Xenakis and F. Chalkiopoulou for their support during the entire study. Dr. D. Tarenidis and Dr. N. Xirokostas are also thanked for performing the XRF and ICP-MS analyses. Dr. D. Tarenidis, V. Spyropoulos and E. Tsapara are thanked for their valuable help in XRD analyses. Dr. G. Oikonomou and M. Sakalis are also thanked for SEM-EDS analyses. Finally, special thanks to P. Patsis for the preparation of thin sections and his valuable help in DTA, as well as M. Christopoulou for designing the map figure.

\section{References}

Aggelidis, Z., 1990. Mud occurrences in Greece and possibilities of exploitation in medical tourism, Proc. of the $2^{\text {nd }}$ Conference for Thermal Mineral Waters, Thessaloniki, 7-9 October 1988, 74-84 (in Greek).

Carretero, M.I., 2002. Clay minerals and their beneficial effects upon human health. A review, Applied Clay Science, 21, 155-163.

Carretero, M.I., Pozo, M., Legido, J.L., Fernández-González, M.V, Delgado, R., Gómez, I., Armijo, F. and Maraver, F., 2014. Assessment of three Spanish clays for their use in pelotherapy, 
Applied Clay Science, 99, 131-143.

Carretero, M.I., Pozo, M., Martín-Rubí, J.A., Pozo, E. and Maraver, F., 2010. Mobility of elements in interaction between artificial sweat and peloids used in Spanish spas, Applied Clay Science, 48, 506-515.

Dellwig, O., Watermann, F., Brumsack, H.J., Gerdes, G. and Krumbein, W.E., 2001. Sulphur and iron geochemistry of Holocene coastal peats (NW Germany): a tool for palaeoenvironmental reconstruction, Palaeogeography, Palaeoclimatology, Palaeoecology, 167, 359-379.

Doner, H.E. and Lynn, W.C., 1989. Carbonate, Halide, Sulfate, and Sulfide minerals. In Dixon, B.J., and Weed, B.S., eds., Minerals in soil environments, Soil Science Society of America, Madison, Wis., USA, 279-330.

Drees, L.R., Wilding, L.P., Smeck, N.E. and Senkayi, A.L., 1989. Silica in soils: Quartz and disordered silica polymorphs. In: Dixon, B.J. and Weed, B.S., eds., Minerals in soil environments, Soil Science Society of America, Madison, Wis., USA, 913-974.

Gee, G.W. and Bauder, J.W., 1986. Particle-size analysis. In: Klute, A., ed., Methods of Soil Analysis (Part 1: Physical and Mineralogical Methods), Soil Science Society of America Inc., American Society of Agronomy Inc., Madison, Wisconsin, 383-411.

Geochemical Atlas of Europe (FOREGS), 2005. Geochemical Atlas of Europe, Part I - Background information, methodology and maps. In: Salminen, R. (Chief editor), Batista, M.J., Bidovec, M., Demetriades, A., De Vivo, B., De Vos, W., Duris, M., Gilucis, A., Gregorauskiene, V., Halamis, J., Heitzmann, P., Lima, A., Jordan, G., Klaver, G., Klein, P., Lis, J., Locutura, J., Marsina, K., Mazreku, A., O'Connor, P.J., Olsson, S.A., Ottesen, R.-T., Petersell, V., Plant, J.A., Reeder, S., Sapeteur, I., Sandstrom, H., Siewers, U., Steenfelt, A. and Tarvainen, T., eds., Geological Survey of Finland.

Gomes, C., Carretero, M.I., Pozo, M., Maraver, F., Cantista, P., Armijo, F., Legido, J.L., Teixeira, F., Rautureau, M. and Delgado, R., 2013. Peloids and pelotherapy: Historical evolution, classification and glossary, Applied Clay Science, 75-76, 28-38.

Gomes, C.D.S.F. and Silva, J.B.P., 2007. Minerals and clay minerals in medical geology, Applied Clay Science, 36, 4-21.

Huang, P.M., 1989. Feldspars, Olivines, Pyroxenes and Amphiboles. In: Dixon, B.J. and Weed, B.S., eds., Minerals in soil environments, Soil Science Society of America, Madison, Wis., USA, 975-1050.

Mitrakas, M., 2009. Physicochemical Characteristics of the Natural Mud Deposits in Sagiada Thesprotia. In: Geothermal Energy in the Spotlight, International Forum. Thessaloniki, Greece (in Greek).

Moore, D.M. and Reynolds, R.C., 1997. X-Ray diffraction and the identification and analysis of clay minerals, Oxford University Press Inc., New York, 378 pp.

Mountrakis, D., 2010. Geology and geotectonic evolution of Greece, University Studio Press, 374 pp. (in Greek).

Paquet, H. and Clauer, N., 1997. Soils and sediments, Mineralogy and Geochemistry, Springer Verlag, Berlin, Heidelberg, 369 pp.

Perrier, R. and Koukouzas, K., 1969. Geological map of Greece: Sayiadha map sheet, scale 1:50,000, Institute for Geology and Subsurface Research.

Veniale, F., Bettero, A., Jobstraibizer, P.G. and Setti, M., 2007. Thermal muds: Perspectives of innovations, Applied Clay Science, 36, 141-147. 